\title{
Desain Pembelajaran Statistika Terapan Berbasis Kasus Berkualitas Baik (Valid, Praktis, dan Efektif) untuk Mahasiswa Pendidikan Matematika
}

\author{
Muhammad Nurhusain $^{1 *}$, Abdul Hadi ${ }^{2}$ \\ ${ }^{1,2}$ Pendidikan Matematika, STKIP YPUP Makassar \\ *e-mail: zein.alhusain@gmail.com \\ (Received: 14-02-2021; Reviewed: 03-03-2021; Accepted: 16-03-2021)
}

\begin{abstract}
Abstrak
Penelitian ini bertujuan untuk mengembangkan desain pembelajaran statistika terapan berbasis kasus yang berkualitas baik yaitu memenuhi kriteria kevalidan, kepraktisan dan keefektifan, pada materi analisis regresi. Penelitian ini merupakan penelitian desain (design research). Penelitian dilakukan dengan mengikuti siklus Mc. Kenney yang terdiri dari tiga fase, yakni: preliminary research, prototyping phase, dan assessment phase, dan menggunakan model pengembangan Dick and Carey yang terdiri dari 11 langkah. Subjek penelitian ini adalah mahasiswa Kelas MT-III.1 Program Studi Pendidikan Matematika STKIP YPUP Makassar semester III tahun akademik 2018/2019, sebanyak 35 orang. Instrumen yang digunakan yaitu: lembar validasi desain pembelajaran, instrumen tes hasil belajar, lembar observasi aktivitas mahasiswa dan kemampuan dosen mengelola pembelajaran, dan angket respon mahasiswa. Data yang diperoleh dianalisis menggunakan analisis statistik deskriptif dan diolah secara kuantitatif dan kualitatif. Hasil yang diperoleh menyatakan bahwa: (1) Desain pembelajaran memenuhi kriteria kevalidan sehingga layak digunakan berdasarkan hasil penilaian 2 (dua) orang validator yang memiliki kompetensi masing-masing dalam bidang pendidikan dan statistika; (2) Kemampuan dosen dalam mengelola pembelajaran sebesar $84,05 \%$, berada pada kategori baik sesuai hasil uji coba desain pembelajaran yang dikembangkan, sehingga desain pembelajaran memenuhi kriteria kepraktisan; (3) Rata-rata hasil belajar mahasiswa mencapai KKM yaitu 82,4 dengan standar deviasi sebesar 8,4 dan ketuntasan klasikal 85,71\% terpenuhi, aktivitas mahasiswa sebesar $89,36 \%$, berada pada kategori aktif, dan respon mahasiswa sebesar 79,05 , berada pada kategori positif, sehingga desain pembelajaran memenuhi kriteria keefektifan. Jadi dapat disimpulkan bahwa desain pembelajaran berbasis kasus untuk perkuliahan statistika terapan mahasiswa pendidikan matematika STKIP YPUP Makassar, berkualitas baik yaitu memenuhi kriteria kevalidan, kepraktisan, dan keefektifan.
\end{abstract}

Kata Kunci: Desain pembelajaran, kualitas pembelajaran, pembelajaran berbasis kasus, pembelajaran statistika

\begin{abstract}
The aims this research is the develop of case-based learning design for applied statistics with good quality that meet the criteria of validity, practicality, and effectiveness, in regression analysis materials. This is a kind of design research. The research was conducted by following the cycle of Mc. Kenney consists of three phases, namely: preliminary research, prototyping phase, and assessment phase, and uses the Dick and Carey development model which consists of 11 steps. The subjects were students of Class MT-III.1 Program Mathematics Education STKIP YPUP Makassar the third semester academic year 2018/2019, as many as 35 people. The instrument that is used is: validation sheets of the learning design, the instrument test of the learning results, observation sheets of students' activities and the lecturer ability to manage learning, and students' responses questionnaire. Data were analyzed with descriptive statistics and processed by quantitative and qualitative. The result showed that: (1) the learning design meets the validity criteria so that it is suitable for use based on the results of the assessment of 2 (two) validators who have their respective competences in the fields of education and statistics; (2) The lecturers ability in managing the learning of $84.05 \%$, is in the good category appropriate the trial results of learning design are developed, so that the learning design meet the practicality criteria; (3) the mean of the students' learning results reached KKM is 82.4 with a standard deviation of 8.4 and completeness of classical $85.71 \%$ is met, the students activity at $89.36 \%$, is in the active category, and the students response at 79,05\%, is in the positive category, so the learning design meets the effectiveness criteria. It was concluded that the case-based learning design for applied statistics lectures for mathematics education students of STKIP YPUP Makassar, is of good quality that meet the criteria of validity, practicality, and effectiveness.
\end{abstract}

Keywords: Learning design, learning quality, case-based learning, statistics learning. 


\section{PENDAHULUAN}

Pengajaran Statistika Terapan pada mahasiswa memberikan suatu tantangan yang besar bagi pengajarnya. Observasi yang dilakukan pada perkuliahan statistika terapan sebelumnya dan hasil wawancara dengan dosen pengampu mata kuliah statistika terapan, diperoleh informasi bahwa materi statistika terapan sulit dipahami oleh mahasiswa terutama pada proses interpretasi hasil analisis data. Selain itu, banyak ditemui mahasiswa dengan kemampuan mengolah data masih rendah. Ditambah lagi, dalam praktik dan teori, kegiatan pembelajaran dilakukan dalam bentuk diskusi. Hal ini menimbulkan kecenderungan bahwa tidak semua siswa aktif di dalam kelas dan siswa yang aktif didominasi oleh mereka yang lebih memahami materi. Sementara itu, mereka yang tidak mahir cenderung diam atau bersikap negatif, dan tidak berani berdebat atau mengungkapkan cara-cara untuk menyelesaikan masalah yang berkaitan dengan kegiatan belajar. Hal ini juga berdampak pada buruknya prestasi akademik siswa. Walaupun banyak faktor yang mempengaruhinya, namun salah satu faktor yang perlu diperhatikan adalah faktor-faktor yang berhubungan dengan inovasi dalam kegiatan pembelajaran dapat meningkatkan kualitas pembelajaran, sehingga proses dan hasil belajar siswa juga diharapkan dapat ditingkatkan.

Berdasarkan hal tersebut perlu dilakukan tindakan untuk meningkatkan kualitas pembelajaran, salah satunya dengan menstimulasi kemampuan belajar siswa. Untuk mengatasi masalah tersebut maka perlu dikembangkan suatu desain pembelajaran. Peneliti tertarik untuk mengembangkan desain pembelajaran berbasis kasus untuk meningkatkan kualitas pembelajaran dalam mata kuliah "Statistik Terapan".

Ada beberapa definisi desain atau rencana. Masing-masing definisi ini memiliki rumus yang berbeda satu sama lain. Cunningham (1982, Uno, 2011) percaya bahwa perencanaan adalah pemilihan dan koneksi pengetahuan, fakta, imajinasi dan asumsi masa depan, dan tujuannya adalah untuk memvisualisasikan dan merumuskan hasil yang diperlukan, urutan kegiatan yang diperlukan, dan perilaku dalam suatu perilaku yang dapat diterima yang akan digunakan dalam penyelesaian. Menurut Sari (2017) "desain pembelajaran merupakan praktik penyusunan media dan konten teknologi komunikasi untuk membantu memungkinkan terjadinya transfer pengetahuan yang efektif antara guru dan siswa". Selain itu menurut Sustiawati et al. (2018) percaya bahwa "desain pembelajaran adalah desain sistem dan sistem untuk mencapai tujuan pembelajaran tertentu". Definisi lain (Steller, 1983, Uno, 2014) menunjukkan bahwa perencanaan adalah hubungan antara apa yang ada sekarang (what is) dan bagaimana seharusnya (what should be) terkait dengan kebutuhan, penetapan tujuan, prioritas, rencana, dan hubungan alokasi sumber daya. Ketika merencanakan berdasarkan definisi ini, fokusnya harus pada mengisi kesenjangan antara keadaan saat ini dan keadaan masa depan untuk memenuhi harapan Anda.

Desain pembelajaran yang dihasilkan diharapkan memenuhi kriteria Nieven (Nurdin, 2007) yaitu pembelajaran yang berkualitas baik dengan memenuhi kriteria valid, praktis, dan efektif. Beberapa hal yang didesain dalam penelitian ini adalah desain pembelajaran dan perangkat yang mendukung desain tersebut. Perangkat yang dimaksud meliputi: (1) Rencana pembelajaran semester (RPS), (2) Satuan acara perkuliahan (SAP), (3) Buku ajar, (4) Lembar kegiatan mahasiswa, (5) Kisi-kisi instrumen tes hasil belajar, (6) Instrumen tes hasil belajar, (7) Jawaban dan rubrik penskoran. Desain pembelajaran yang akan dikembangkan membutuhkan strategi pembelajaran yang tepat untuk meningkatkan kualiats pembelajaran, salah satunya yaitu pembelajaran berbasis kasus. 
Menurut Safitri \& Purbaningrum (2020), "pembelajaran berbasis kasus (case based learning) adalah pembelajaran berpusat pada mahasiswa dengan menggunakan kasus sebagai topik dalam pembelajaran". Pendapat lain mengatakan bahwa pembelajaran kasus melibatkan kondisi interaktif, eksplorasi mahasiswa terhadap situasi realistik dan spesifik (Mutmainnah, 2008). Case based learning melibatkan mahasiswa pada pengambilan keputusan terhadap pertanyaan-pertanyaan yang tidak hanya memiliki satu jawaban yang benar (Gultom, 2010). Menurut Ulfiyani (2018) bahwa "pembelajaran berbasis kasus layak diterapkan karena memberikan dua keuntungan, yaitu (1) dapat mengembangkan keterampilan berbicara mahasiswa berbasis pengalaman belajar langsung, dan (2) mahasiswa berkesempatan mengembangkan keterampilan berpikir kritis melalui kegiatan memecahkan sebuah kasus". Selain itu, menurut Rismawati \& Jasman (2014), "CBL berpengaruh positif terhadap pemahaman mata kuliah perpajakan dan namun tidak berpengaruh signifikan". Dalam pembelajaran berbasis kasus, mahasiswa menghadapi masalah praktis yang harus ditangani sesuai dengan pengetahuan mereka sendiri (Sutomo, 2007).

Hasil penelitian Saputra et al. (2017) menyatakan bahwa "metode case based learning berpengaruh positif terhadap pemahaman mahasiswa". Sejalan dengan itu, Haryanto \& Khairudin (2014) mengatakan bahwa "terdapat pengaruh yang signifikan pembelajaran berbasis kasus terhadap kemampuan pemahaman kognitif mahasiswa". Lebih lanjut, menurut Dewi \& Hamid (2015), hasil penelitiannya mengungkap bahwa "model pembelajaran Case Based Learning (CBL) berpengaruh secara signifikan terhadap pemahaman konsep siswa". Selain itu, Romlah et al. (2013) mengatakan bahwa "ada peningkatan hasil belajar yang signifikan setelah dilakukan pembelajaran kooperatif berbasis kasus bervisi SETS”.

Lebih lanjut, menurut Dahri et al., (2018) bahwa,

"Perkuliahan pendidikan Pancasila berbasis kasus dengan metode diskusi yang dilaksanakan menunjukkan respon yang baik dari mahasiswa penerapan perkuliahan berbasis kasus dengan metode diskusi dapat berjalan dengan lancar apabila di dukung dengan media pembelajaran yang memadai seperti modul, bahan ajar dan fasilitas pendukung perkuliahan, dan penerapan perkuliahan berbasis kasus harus memiliki rencana pembelajaran yang disusun berdasarkan kondisi mahasiswa".

Ciri-ciri utama CBL yang berasal dari PBL (Williams, 2005) adalah:

1. Kasus digunakan untuk merangsang dan mendukung perolehan pengetahuan, keterampilan, dan sikap.

2. Kasus menempatkan kejadian dalam konteks atau situasi yang mempromosikan pembelajaran otentik.

3. Kasus umumnya ditulis sebagai masalah yang memberi siswa situasi dunia nyata.

4. CBL memungkinkan siswa untuk mengembangkan pendekatan kolaboratif berbasis tim untuk pendidikan mereka.

5. Karakteristik lainnya termasuk generasi hipotesis dan konsolidasi dan integrasi kegiatan pembelajaran.

Berdasarkan uraian di atas, perlu dilakukan inovasi pembelajaran dalam rangka perbaikan kegiatan pembelajaran dengan mendesain pembelajaran berbasis kasus yang berkualitas baik 
yaitu memenuhi kriteria kevalidan, kepraktisan dan kefektifan untuk perkuliahan statistika terapan mahasiswa pendidikan matematika STKIP YPUP Makassar.

\section{Metode}

Jenis penelitian ini adalah desain research. Subjek penelitian ini adalah mahasiswa Kelas MT-III.1, Program Studi Pendidikan Matematika STKIP YPUP Makassar semester III tahun akademik 2018/2019, sebanyak 35 orang. Penelitian dilaksanakan di Program Studi Pendidikan Matematika STKIP YPUP Makassar.

Prosedur penelitian ini merupakan gabungan dari siklus Mc. Kenney dan alur pengembangan model Dick \& Carey sebagai prosedur pengembangan desain pembelajaran (Nurhusain, 2012).

1. Preliminary research (penelitian pendahuluan), meliputi:

a. Analisis kebutuhan dan analisis isi: Menentukan tujuan pembelajaran (identify an instructional goal), Melakukan analisis pembelajaran (conduct an instructional analysis), melakukan input perilaku dan karakteristik mahasiswa (identify entry behaviors and characteristics).

b. Kajian pustaka

c. Kembangkan kerangka penelitian konseptual atau teoritis: Rumusan tujuan performansi.

2. Prototyping phase (tahap prototyping), meliputi:

a. Mengembangkan butir-butir tes acuan patokan (develop criterion referenced test items).

b. Mendesain pembelajaran: Merancang sebuah strategi pembelajaran (desain an instructional strategy).

c. Mengembangkan dan memilih material pembelajaran (develop and select instructional materials). Mengembangkan dan memilih material pembelajaran sesuai rancangan strategi pembelajaran yang telah dirancang yaitu Satuan Acara Perkuliahan (SAP), Buku Ajar dan Lembar Kerja Mahasiswa (LKM). Mendesain Instrumen, yang terdiri lembar observasi aktivitas mahasiswa dan lembar observasi pengelolaan pembelajaran, angket respons mahasiswa dan tes hasil belajar.

3. Assessment phase (tahap penilaian), meliputi:

a. Penilaian

1) Desain dan pelaksanaan evaluasi formatif:

(1) Validitas isi

(2) Validitas konstruk

2) Revisi bahan pembelajaran.

b. Tahap uji coba

Desain dan pelaksanaan evaluasi sumatif: Penilaian kepraktisan dan keefektifan pembelajaran yaitu dengan mengamati aktivitas mahasiswa, mengamati kemampuan dosen mengelola pembelajaran, respon mahasiswa terhadap proses dan perangkat pembelajaran, dan hasil dari tes hasil belajar.

Setelah dilakukan evaluasi dan pengujian, penulis menyimpulkan apakah solusi atau intervensi tersebut memenuhi spesifikasi yang telah ditentukan sebelumnya. Jika tidak, harus diperbaiki. Prosedur pengembangan tergambar pada gambar 1 . 


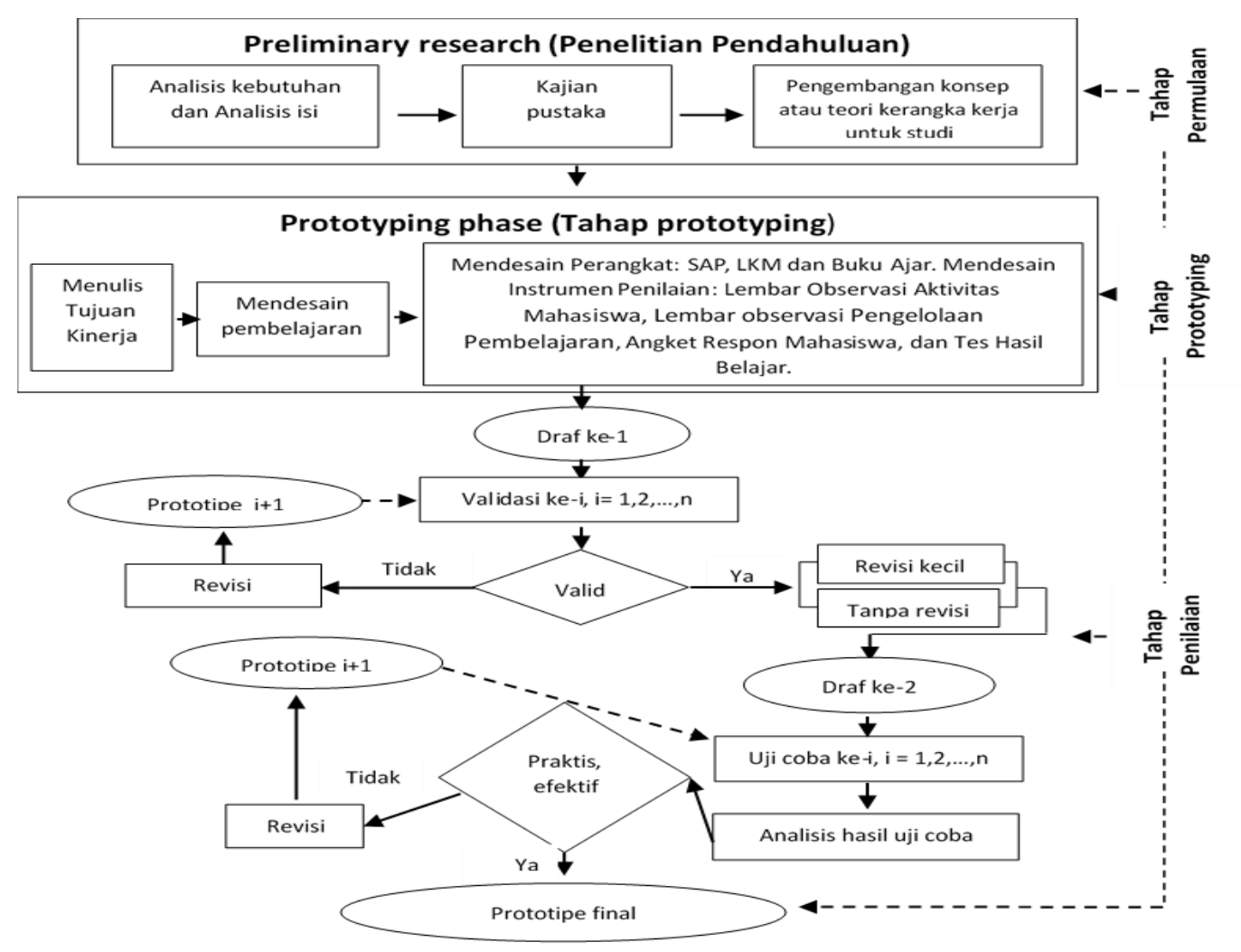

Gambar 1. Diagram Prosedur Pengembangan Desain

Keterangan:

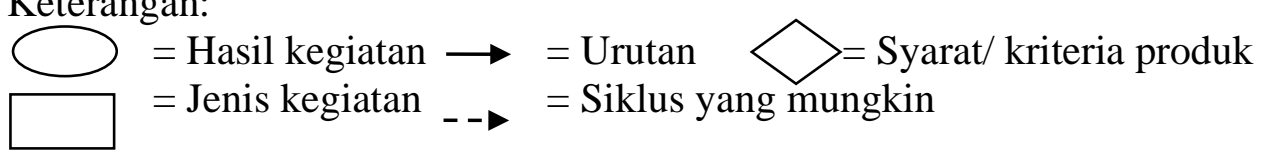

Adapun data, sumber data, instrumen, dan prosedur pengambilan data pada penelitian ini dicantumkan pada Tabel 1 .

Tabel 1. Data, Sumber Data, Instrumen, dan Prosedur Pengambilan Data

\begin{tabular}{|c|c|c|c|c|}
\hline No & Data & $\begin{array}{l}\text { Sumber } \\
\text { Data }\end{array}$ & Instrumen & $\begin{array}{c}\text { Prosedur } \\
\text { pengambilan data }\end{array}$ \\
\hline 1. & $\begin{array}{l}\text { Kevalidan } \\
\text { desain dan } \\
\text { perangkat } \\
\text { pembelajaran }\end{array}$ & $\begin{array}{l}\text { Desain dan } \\
\text { perangkat } \\
\text { pembelajaran }\end{array}$ & $\begin{array}{l}\text { Lembar } \\
\text { validasi }\end{array}$ & $\begin{array}{l}\text { Desain dan perangkat } \\
\text { pembelajaran divalidasi } \\
\text { oleh dua orang } \\
\text { pakar/ahli. }\end{array}$ \\
\hline 2. & $\begin{array}{l}\text { Kemampuan } \\
\text { dosen } \\
\text { mengelola } \\
\text { pembelajaran } \\
\text { berbasis kasus }\end{array}$ & Dosen & $\begin{array}{l}\text { Lembar } \\
\text { observasi } \\
\text { kemampuan } \\
\text { dosen } \\
\text { mengelola } \\
\text { pembelajaran }\end{array}$ & $\begin{array}{l}\text { Merekam kemampuan } \\
\text { dosen mengelola } \\
\text { pembelajaran pada } \\
\text { lembar observasi } \\
\text { kemampuan dosen } \\
\text { mengelola } \\
\text { pembelajaran }\end{array}$ \\
\hline
\end{tabular}




\begin{tabular}{|c|c|c|c|c|}
\hline No & Data & $\begin{array}{l}\text { Sumber } \\
\text { Data }\end{array}$ & Instrumen & $\begin{array}{c}\text { Prosedur } \\
\text { pengambilan data }\end{array}$ \\
\hline 3. & $\begin{array}{l}\text { Aktivitas } \\
\text { mahasiswa }\end{array}$ & Mahasiswa & $\begin{array}{l}\text { Lembar } \\
\text { observasi } \\
\text { aktivitas }\end{array}$ & $\begin{array}{l}\text { Merekam aktivitas } \\
\text { mahasiswa pada lembar } \\
\text { observasi aktivitas }\end{array}$ \\
\hline 4. & $\begin{array}{l}\text { Respon } \\
\text { mahasiswa }\end{array}$ & Mahasiswa & $\begin{array}{l}\text { Angket respon } \\
\text { mahasiswa }\end{array}$ & $\begin{array}{l}\text { Memberikan angket } \\
\text { pada mahasiswa }\end{array}$ \\
\hline 5. & $\begin{array}{l}\text { Skor tes hasil } \\
\text { belajar }\end{array}$ & Mahasiswa & $\begin{array}{l}\text { Soal tes hasil } \\
\text { belajar }\end{array}$ & $\begin{array}{l}\text { Memberikan tes pada } \\
\text { akhir pembelajaran }\end{array}$ \\
\hline
\end{tabular}

Teknik analisis data untuk menganalisis data kevalidan desain pembelajaran berbasis kasus. Kevalidan desain dan perangkat pembelajaran berbasis kasus oleh dua validator/ahli. Kriteria yang digunakan untuk memutuskan bahwa desain pembelajaran berbasis kasus yang terdiri dari Buku Ajar, LKM, RPS, SAP, dan Instrumen tes hasil belajar memiliki derajat validitas yang memadai adalah nilai V untuk setiap aspek minimal berada dalam kategori "valid".

Selanjutnya, analisis data keparaktisan desain pembelajaran yaitu dengan menganalisis data keterlaksanaan pembelajaran berbasis kasus yang dianalisis secara kualitatif. Evaluasi untuk mengetahui kelayakan pembelajaran yaitu kemampuan dosen dalam mengelola kegiatan pembelajaran matematika sesuai dengan satuan acara perkuliahan (SAP) melalui model pembelajaran berbasis kasus. Adapun penentuan kategori aspek keterlaksanaan pembelajaran dalam proses pembelajaran, yaitu sesuai kriteria berikut berdasarkan rumus:

$$
P=\frac{f}{N} \times 100 \%
$$

Keterangan:

$\mathrm{P}$ : Persentase kategori keterlaksanaan pembelajaran

$\mathrm{f}$ : Jumlah rata-rata nilai yang diperoleh dari setiap aspek pengamatan kemampuan mengelola pembelajaran

$\mathrm{N}$ : Nilai maksimal dari keseluruhan aspek pengamatan kemampuan mengelola pembelajaran

Kriteria yang digunakan untuk menentukan kategori keterlaksanaan pembelajaran adalah minimal berada pada kategori Baik, berdasarkan teknik kategori persentase keterlaksanaan pembelajaran pada tabel 2 .

Tabel 2. Kriteria Persentase Kemampuan Mengelola Pembelajaran

\begin{tabular}{cc}
\hline Persentase \% & Kategori \\
\hline $85-100$ & Sangat baik \\
$70-86$ & Baik \\
$55-69$ & Sedang \\
$50-54$ & Kurang \\
$0-49$ & Sangat Kurang \\
\hline
\end{tabular}

Adaptasi dari Supriyadi (2013) 
Selanjutnya, analisis data keefektifan desain pembelajaran berbasis kasus yang terdiri dari tiga hal, yaitu (1) Analisis data aktivitas mahasiswa, (2) Analisis data respon mahasiswa, dan (3) Analisis data tes hasil belajar.

Gunakan persentase untuk menganalisis data observasi aktivitas siswa selama aktivitas pembelajaran. Adapun penentuan kategori aspek aktivitas mahasiswa, yaitu sesuai kriteria berikut berdasarkan rumus:

$$
\mathrm{P}=\frac{\mathrm{f}}{\mathrm{N}} \times 100 \%
$$

Keterangan:

$\mathrm{P}$ : Persentase kategori aktivitas mahasiswa

f : Jumlah rata-rata nilai yang diperoleh dari setiap aspek pengamatan aktivitas mahasiswa

$\mathrm{N}$ : Nilai maksimum dari keseluruhan aspek pengamatan aktivitas mahasiswa

Kriteria yang digunakan untuk menentukan apakah aktivitas mahasiswa memadai selama pembelajaran berbasis kasus setidaknya ada dalam kategori "aktif", berdasarkan teknik kategori persentase aktivitas mahasiswa pada tabel 3 .

Tabel 3. Kategori Aspek Aktivitas Mahasiswa

\begin{tabular}{cc}
\hline Persentase \% & Kategori \\
\hline $85-100$ & Sangat aktif \\
$70-86$ & Aktif \\
$55-69$ & Sedang \\
$50-54$ & Kurang \\
$0-49$ & Sangat Kurang \\
\hline \multicolumn{2}{r}{ Adaptasi dari Supriyadi (2013) }
\end{tabular}

Data respon mahasiswa dianalisis dengan melihat presentase dari respons mahasiswa. Persentase ini dapat dihitung dengan menggunakan rumus:

$$
\mathrm{P}=\frac{\mathrm{f}}{\mathrm{N}} \times 100 \% \text {, }
$$

Keterangan:

$\mathrm{P}=$ Persentase kategori respon mahasiswa yang menjawab ya

$\mathrm{f}=$ Frekuensi mahasiswa yang menjawab ya

$\mathrm{N}=$ Banyaknya mahasiswa yang mengisi angket

Kriteria yang digunakan untuk menentukan apakah respon mahasiswa memadai selama pembelajaran berbasis kasus setidaknya ada dalam kategori "positif", berdasarkan teknik kategori persentase respon mahasiswa pada tabel 4 .

Tabel 4. Kategori Respon Mahasiswa

\begin{tabular}{cc}
\hline Persentase $\%$ & Kategori \\
\hline $85-100$ & Sangat Positif \\
$70-86$ & Positif \\
\hline
\end{tabular}




\begin{tabular}{cc}
\hline $55-69$ & Sedang \\
$50-54$ & Kurang \\
$0-49$ & Sangat Kurang \\
\hline \multicolumn{2}{c}{ Adaptasi dari Supriyadi (2013) }
\end{tabular}

Kriteria yang digunakan untuk menentukan skor seperti pada tabel 5.

Table 5 Kategorisasi Hasil Belajar

\begin{tabular}{cc}
\hline Skor $(\%)$ & Kategori Hasil Belajar \\
\hline $0-54$ & Sangat Rendah \\
$55-59$ & Rendah \\
$60-75$ & Sedang \\
$76-85$ & Tinggi \\
$86-100$ & Sangat Tinggi \\
\hline & Adaptasi dari Purwanto (2013)
\end{tabular}

Dalam mata kuliah statistika terapan, standar kriteria ketuntasan minimal (SKKM) yang harus dipenuhi mahasiswa adalah nilai minimal level $\mathrm{B}$ atau nilai minimal 75 poin. Jika $\mathrm{S} \geq 75$ siswa, siswa akan mencapai ketuntasan individu. Jika minimal $85 \%$ siswa mencapai nilai minimal 75 poin, maka ketuntasan klasikal dapat dicapai.

\section{Hasil}

\section{Analisis Kevalidan Desain Pembelajaran}

Secara umum, hasil penilaian para ahli terhadap desain pembelajaran yang meliputi Buku Desain, Buku Ajar, LKM, THB, RPS, dan SAP dapat dilihat pada tabel 6.

Tabel 6. Rangkuman Hasil Validasi Desain Pembelajaran

\begin{tabular}{lcc}
\hline Sumber & Skor Rata-rata & Kriteria \\
\hline Buku Desain & 3,94 & Valid \\
Lembar Kegiatan Mahasiswa & 4,00 & Valid \\
Rencana Pembelajaran Semester & 4,19 & Valid \\
Satuan Acara Perkuliahan & 4,19 & Valid \\
Buku Ajar & 4,17 & Valid \\
Tes Hasil Belajar & 4,13 & Valid \\
\hline
\end{tabular}

Berdasarkan Tabel 6 dapat disimpulkan bahwa hasil penilaian para ahli pada desain pembelajaran yang digunakan meliputi Buku Desain, RPS, SAP, Buku Ajar, LKM dan Tes Hasil Belajar berada pada kategori "Valid" $3,5 \leq \bar{X}<4,5$. Hal ini berarti desain pembelajaran tersebut telah layak untuk diujicobakan.

\section{Analisis kepraktisan desain pembelajaran}


Dalam analisis data pelaksanaan pembelajaran berbasis kasus, dapat dilihat analisis data kepraktisan desain pembelajaran berbasis kasus. Analisis data keterlaksanaan pembelajaran berbasis kasus yang dimaksud di sini adalah kemampuan dosen dalam mengelola pembelajaran berbasis kasus.

Tabel 7. Analisis Data Kemampuan Dosen Mengelola Pembelajaran Berbasis Kasus

\begin{tabular}{cccc}
\hline Nilai yang Diperoleh & Nilai Maksimum & Persentase (\%) & Kategori \\
\hline 1365 & 1624 & 84,05 & Baik \\
\hline
\end{tabular}

Berdasarkan tabel 7, diketahui bahwa kemampuan dosen mengelola pembelajaran berbasis kasus menunjukkan rata-rata persentase yaitu $84,05 \%$. Hasil tersebut menunjukkan bahwa pelaksanaan pembelajaran dalam proses pembelajaran termasuk dalam kategori baik, sehingga desain pembelajaran berbasis kasus memenuhi kriteria kepraktisan.

\section{Analisis keefektifan desain pembelajaran}

(1) Aktivitas mahasiswa. Instrumen observasi aktivitas mahasiswa digunakan untuk mengamati proses kegiatan pembelajaran berbasis kasus pada perkuliahan statistika terapan untuk mengamati semua aktivitas mahasiswa selama kegiatan pembelajaran. Hasil analisis data aktivitas mahasiswa disajikan pada tabel 8 .

Tabel 8. Analisis Data Aktivitas Mahasiswa dengan Menerapkan Model pembelajaran Berbasis Kasus

\begin{tabular}{cccc}
\hline Nilai yang Diperoleh & Nilai Maksimum & Persentase (\%) & Kategori \\
\hline 1151 & 1288 & 89,36 & Sangat Aktif \\
\hline
\end{tabular}

Berdasarkan tabel 8, diketahui bahwa aktivitas mahasiswa dengan menerapkan pembelajaran berbasis kasus menunjukkan rata-rata persentase aktivitas mahasiswa yaitu $89,36 \%$. Hasil tersebut menunjukkan bahwa partisipasi dan antusiasme siswa dalam proses pembelajaran termasuk dalam kategori "aktif".

(2) Respon mahasiswa. Instrumen angket respon mahasiswa digunakan untuk mengetahui respon mahasiswa terhadap penerapan model pembelajaran berbasis kasus pada perkuliahan statistika terapan. Hasil analisis data respon mahasiswa disajikan pada tabel 9.

Tabel 9. Analisis Data Respon Mahasiswa Terhadap Desain Pembelajaran Berbasis Kasus

\begin{tabular}{cccc}
\hline Nilai yang Diperoleh & Nilai Maksimum & Persentase (\%) & Kategori \\
\hline 830 & 1050 & 79,05 & Positif \\
\hline
\end{tabular}

Berdasarkan tabel 9, diketahui bahwa respon mahasiswa terhadap desain pembelajaran berbasis kasus menunjukkan rata-rata persentase respon mahasiswa yaitu 79,05\%. Hasil tersebut menunjukkan bahwa tanggapan atau respon mahasiswa terhadap kegiatan pembelajaran dengan menggunakan desain pembelajaran berbasis kasus berada pada kategori Positif. 
(3) Hasil tes belajar. Hasil analisis deskriptif skor tes hasil belajar mahasiswa setelah pembelajaran dengan menggunakan desain pembelajaran berbasis kasus dapat dilihat pada tabel 10.

Tabel. 10 Analisis Skor Tes Hasil Belajar Statistika Terapan Mahasiswa Kelas MT-III.1 Program Studi Pendidikan Matematika STKIP YPUP Makassar

\begin{tabular}{lc}
\hline \multicolumn{1}{c}{ Statistik Deskriptif } & Nilai \\
\hline Ukuran subjek & 35 \\
Skor ideal & 100 \\
Skor terendah & 60 \\
Skor tertinggi & 95 \\
Rentang skor & 35 \\
Skor rata-rata & 82,40 \\
Standar deviasi & 8,40 \\
Variansi & 70,48 \\
\hline
\end{tabular}

Pada tabel 10 menunjukkan bahwa hasil belajar mahasiswa kelas MT-III.1 Program Studi Pendidikan Matematika STKIP YPUP Makassar terhadap perkuliahan Statistika Terapan skor rata-rata diperoleh adalah 82,40 dengan standar deviasi 8,4. Jika skor hasil belajar dikelompokkan dalam lima kategori, maka diperoleh tabel 11.

\section{Tabel 11. Distribusi Frekuensi dan Persentase Skor Hasil Belajar Statistika Terapan Mahasiswa Kelas MT-III.1 Program Studi Pendidikan Matematika STKIP YPUP Makassar}

\begin{tabular}{|c|c|c|c|}
\hline Skor & Kategori & Frekuensi & Persentase (\%) \\
\hline $0-54$ & Sangat Rendah & - & 0 \\
\hline $55-59$ & Rendah & - & 0 \\
\hline $60-75$ & Sedang & 7 & 20 \\
\hline $76-85$ & Tinggi & 15 & 42,86 \\
\hline $86-100$ & Sangat Tinggi & 13 & 37,14 \\
\hline \multicolumn{2}{|c|}{ Jumlah } & 35 & 100 \\
\hline
\end{tabular}

Tabel 11 menunjukkan bahwa dari 35 mahasiswa yang mengikuti tes hasil belajar, 20\% berada pada kategori sedang, $42,86 \%$ pada kategori tinggi, dan $37,14 \%$ pada kategori sangat tinggi. Hal ini menunjukkan bahwa pemahaman mahasiswa terhadap materi yang disajikan menggunakan model pembelajaran berbasis kasus berbeda-beda, dan dari data tersebut terlihat bahwa pemahaman mahasiswa cenderung tinggi atau sangat tinggi.

Tabel 12. Deskripsi Kuantitatif Ketuntasan Hasil Belajar Statistika Terapan Mahasiswa Kelas MT-III.1 Program Studi Pendidikan Matematika STKIP YPUP Makassar

\begin{tabular}{cccc}
\hline Perolehan Skor & Kategori & Frekuensi & Persentase (\%) \\
\hline $0-74$ & Tidak tuntas & 5 & $14,29 \%$ \\
$75-100$ & Tuntas & 30 & $85,71 \%$ \\
\hline
\end{tabular}


Tabel 12 menunjukkan jumlah mahasiswa yang lulus atau mencapai ketuntasan individu sebanyak 30 dari 35 mahasiswa yaitu sekitar 85,71\%. Dengan demikian yang belum tuntas adalah 5 dari 35 mahasiswa atau sekitar 14,29\%. Data ini menunjukkan bahwa ketuntasan klasikal terpenuhi.

Berdasarkan ketiga kriteria keefektifan, semua aspek terpenuhi dalam penelitian yaitu: respon mahasiswa, tes hasil belajar dan aktivitas siswa. Berdasarkan kriteria keefektifan dapat disimpulkan bahwa dalam pembelajaran desain pembelajaran berhasil karena memenuhi 3 indikator keefektifan.

Hasil yang diperoleh di atas menunjukkan bahwa berdasarkan penilaian para ahli dan hasil uji coba yang dilakukan, desain pembelajaran telah memenuhi kriteria kevalidan, kepraktisan, dan keefektifan. Oleh karena itu dapat disimpulkan bahwa hasil desain pembelajaran berbasis kasus yang digunakan guru dapat meningkatkan kualitas pembelajaran pada mata kuliah statistika terapan.

\section{Pembahasan}

Hasil pengujian yang dilakukan dapat digunakan untuk memeriksa sejauh mana kelayakan desain yang telah dirancang. Desain pembelajaran yang telah dirancang dalam hal ini adalah buku desain, lembar kegiatan mahasiswa, satuan acara perkuliahan, buku ajar dan tes hasil belajar yang dinilai berdasarkan nilai validitas, nilai kepraktisan dan nilai keefektifan dari desain tersebut. Pembahasan ketiga hal di atas dikemukakan berikut ini:

\section{Kevalidan}

Pada bagian hasil penelitian telah dikemukakan mengenai uji kevalidan, berdasarkan alasan tersebut dapat disimpulkan bahwa prototipe/draft (Buku desain, RPS, SAP, LKM, Buku Ajar, THB, angket respons mahasiswa, pengamatan pengelolaan pembelajaran, dan pengamatan aktivitas mahasiswa) secara keseluruhan telah memenuhi kriteria kevalidan.

Hasil evaluasi ahli pendidikan matematika menunjukkan bahwa desain pembelajaran berbasis kasus di semua aspek dapat dikatakan valid, namun masih ada saran perbaikan yang perlu diperhatikan guna mencapai desain yang sempurna. Setelah direvisi, desain pembelajaran ini dapat digunakan dalam proses pembelajaran matematika. Selain itu, penyajian materi yang terdapat dalam buku teks merupakan penyajian dengan struktur yang dibuat sendiri oleh mahasiswa. Konstruksi yang dilakukan mahasiswa menyangkut materi perkuliahan statistika terapan berupa pengetahuan deklaratif, prosedural, dan kondisional.

\section{Kepraktisan}

Hasil uji coba desain pembelajaran yang dirancang untuk mendapatkan nilai kepraktisan diperoleh dari observasi. Terbukti bahwa dalam mengimplementasikan setiap langkah implementasi case-based learning, dosen model dapat bekerja dengan baik, atau dengan kata lain dosen model dapat mengikuti kalimat dengan baik dalam desain pembelajaran yang dirancang. Selain itu, tampaknya desain yang dikembangkan mampu membimbing mahasiswa untuk menemukan jawabannya sendiri-sendiri. Dengan demikian, dapat dikatakan bahwa secara 
praktis, desain dan perangkat yang dikembangkan sejalan dengan desain yaitu RPS, SAP, LKM, THB, dan Buku Ajar, dapat digunakan dalam pembelajaran berbasis kasus.

Secara teoritis, hasil penilaian ahli bidang pendidikan matematika dan statistik pada desain pembelajaran berbasis kasus menunjukkan bahwa desain tersebut layak digunakan dalam pembelajaran. Secara empiris berdasarkan hasil observasi pola pembelajaran single observer ditemukan bahwa proses pembelajaran berjalan dengan baik selama pembelajaran. Berdasarkan hasil penilaian observer, desain pembelajaran memenuhi kriteria kepraktisan.

\section{Keefektifan}

Telah dikemukakan kriteria keefektifan desain pembelajaran yang meliputi: (1) Tes hasil belajar, (2) aktivitas mahasiswa, (3) respon mahasiswa. Skor yang diperoleh mahasiswa dari tes hasil belajar memenuhi ketuntasan klasikal yaitu minimal $85 \%$ dari keseluruhan mahasiswa mencapai ketuntasan individu. Sedangkan rata-rata hasil belajar mahasiswa kelas MT-III.1 Program Studi Pendidikan Matematika STKIP YPUP Makassar terhadap perkuliahan Statistika Terapan diperoleh skor rata-rata 82,40 dari skor ideal 100 dengan standar deviasi 8,4. Aktivitas mahasiswa mencapai kategori aktif. Melalui kasus yang diangkat dari dunia nyata, menjadikan siswa lebih aktif berdiskusi secara kolaboratif, sedangkan pada kriteria respon mahasiswa, juga mememuhi kategori positif. Melalui kasus yang diambil dari dunia nyata menjadikan pembelajaran lebih otentik sehingga mahasiswa memberikan ketertarikan dan respon positif. Hal tersebut sejalan dengan hasil penelitian Thistlethwaite et al. (2012) bahwa siswa menikmati CBL dan berpikir bahwa itu meningkatkan pembelajaran mereka dan guru menikmati CBL karena dianggap memotivasi siswa. Selain itu, Nurhusain (2017) mengungkapkan bahwa "model pembelajaran kooperatif berbasis kasus dapat meningkatkan kualitas pembelajaran, baik dari kualitas proses pembelajaran maupun dari segi kualitas hasil belajar". Berdasarkan hasil pengamatan di lapangan, ketiga aspek keefektifan memenuhi kriteria. Artinya, desain pembelajaran statistika terapan berbasis kasus telah memenuhi kriteria keefektifan.

Hasil penelitian ini sejalan dengan kriteria yang ditetapkan oleh Nieven (Nurdin, 2007) yaitu pembelajaran yang berkualitas baik dengan memenuhi kriteria valid, praktis, dan efektif. Selain itu, hasil penelitian ini juga sejalan dengan Nurhusain (2012) bahwa "desain pembelajaran kooperatif berbasis kasus memenuhi kriteria kevalidan, kepraktisan dan keefektifan". Perbedaannya adalah penelitian ini tidak menggunakan model pembelajaran kooperatif dalam menerapkan pembelajaran berbasis kasus.

\section{Kesimpulan}

Kesimpulan yang dapat diambil dari penelitian ini adalah desain pembelajaran statistika terapan berbasis kasus pada kategori MT-III.1 Program Studi Pendidikan Matematika STKIP YPUP Makassar Semester Ganjil Tahun Akademik 2017/2018 berkualitas baik yaitu memenuhi kriteria kevalidan, kepraktisan, dan keefektifan. Ini didasarkan pada hasil yang diverifikasi oleh para ahli dan hasil tes terbatas. Hasil penelitian menemukan bahwa desain pembelajaran yang dikembangkan memenuhi standar validitas dan mudah digunakan. Pelaksanaan pembelajaran dari desain pembelajaran statistika terapan berbasis kasus sudah baik dilihat dari perspektif kemampuan mengelola pembelajaran oleh guru, dan rata-rata kemampuan belajar mahasiswa hasilnya lebih tinggi dari nilai KKM (standar ketuntasan minimal) dan mencapai ketuntasan 
klasikal, respon mahasiswa terhadap pembelajaran statistika terapan berbasis kasus adalah positif, dan mahasiswa aktif belajar secara keseluruhan.

Batasan penelitian yang akan dikemukakan yaitu keterbatasan selama proses desain pembelajaran, terkait dengan pelaksanaan desain pembelajaran di kelas dan kesiapan yang diperlukan untuk memperoleh desain pembelajaran. Kelemahan penelitian yang disajikan adalah kelemahan yang diakibatkan oleh keterbatasan penelitian, terutama kelemahan proses penelitian. Penelitian ini memiliki beberapa keterbatasan yaitu uji coba lapangan hanya dapat dilakukan dalam satu kelas yaitu Kelas MT-III.1 Program Studi Pendidikan Matematika STKIP YPUP Makassar. Untuk mendapatkan masukan yang lebih banyak, sebaiknya tidak hanya melakukan uji coba lapangan dalam satu kelas, tetapi diujicobakan dalam beberapa kelas. Karena keterbatasan, peneliti tidak dapat melakukan uji coba lapangan tersebut di lebih dari satu kelas.

Bagi tenaga pendidik khususnya dosen, disarankan desain pembelajaran statistika terapan berbasis kasus dapat dijadikan pedoman atau contoh dalam mengimplementasikan desain pembelajaran pada disiplin ilmu lain. Lebih spesifik lagi penggunaan desain pembelajaran berbasis kasus juga dapat dipelajari pada disiplin ilmu lain di luar, baik pada program studi pendidikan matematika maupun di luar program studi tersebut. Harapannya semua kelemahan dan keterbatasan penelitian ini dapat dipelajari, sehingga penelitian yang akan dilakukan dapat lebih sempurna dibandingkan penelitian ini.

\section{Ucapan Terima Kasih}

Ucapan terima kasih yang tidak terhingga kepada:

1. RISTEKDIKTI yang telah mendanai penelitian ini.

2. Civitas akademika STKIP YPUP Makassar yang berkontribusi dalam penelitian ini.

3. Validator dan Observer.

4. Seluruh subjek dalam penelitian ini, mahasiswa Kelas MT-III.1 Program Studi Pendidikan Matematika STKIP YPUP Makassar Semester Ganjil Tahun Akademik 2017/2018.

5. Semua pihak yang berkontribusi dalam penelitian ini.

\section{Referensi}

Dahri, M., Riski, M., \& Ariansyah. (2018). Analisis Sikap Mahasiswa Terhadap Mata Kuliah Pancasila Berbasis Kasus dengan Metode Diskusi. EKOPENDIA: Jurnal Ekonomi Dan Pendidikan, $3(1)$,

$1-12$. http://journal.stkipypmbangko.ac.id/index.php/ekopendia/article/view/152

Dewi, C. A., \& Hamid, A. (2015). Pengaruh Model Case Based Learning (CBL) Terhadap Keterampilan Generik Sains dan Pemahaman Konsep Siswa Kelas X Pada Materi Minyak Bumi. Hydrogen: Jurnal Kependidikan Kimia, 3(2), 294-301. https://doi.org/10.33394/hjkk.v3i2.687

Gultom, A. (2010). Pengaruh Metode Pembelajaran Berbasis Kasus dan Penggunaan Simulator PLC Terhadap Hasil Belajar Mahasiswa Teknik Otomasi Politeknik TEDC. Tesis. PPs UPI. Bandung.

Haryanto, H., \& Khairudin, M. (2014). Implementasi Pembelajaran Kooperatif Berbasis Kasus 
untuk Meningkatkan Efektivitas Pembelajaran Kecerdasan Buatan. Jurnal Pendidikan Teknologi Dan Kejuruan UNY, 22(1), 36-45. https://doi.org/10.21831/jptk.v22i1.8849

Mutmainnah, S. (2008). Pengaruh Penerapan Metode Pembelajaran Kooperatif Berbasis Kasus yang Berpusat pada Mahasiswa Terhadap Efektivitas Pembelajaran Akuntansi Keperilakuan. Simposium Nasional Akuntansi 11 (SNA 11), Universitas Tanjung Pura Pontianak. http://eprints.undip.ac.id/17165/

Nurdin, (2007). Model Pembelajaran Matematika yang Menumbuhkan Kemampuan Metakognitif untuk Menguasai Bahan Ajar. Disertasi. PPs UNESA. Surabaya.

Nurhusain, M. (2012). Pengembangan Desain Pembelajaran Kooperatif Berbasis Kasus pada Siswa Kelas VII.3 SMP Negeri 1 Bontoramba. Tesis. PPs UNM. Makassar.

Nurhusain, M. (2017). Quality Learning Through Cooperative Learning Model Based on Cases. 5(2), 1-15. https://ojs.unm.ac.id/JDM/article/view/3330/1918

Rismawati, \& Jasman, J. (2014). Pengaruh Penerapan Metode Pembelajaran Kooperatif berbasis Kasus yang Berpusat pada Mahasiswa terhadap Efektivitas Pembelajaran Perpajakan. Jurnal Akuntansi, 01(02), 65-83. http://dx.doi.org/10.35906/ja001.v1i2.107

Romlah, S., Binadja, A., \& Santosa, N. (2013). Keefektivan Pembelajaran Kooperatif Bervisi SETS Terhadap Hasil Belajar Siswa. School Science and Mathematics, 2(3), 134. https://journal.unnes.ac.id/sju/index.php/chemined/article/view/1573

Safitri, P. T., \& Purbaningrum, K. A. (2020). Pengembangan Buku Ajar Berbasis Kasus (Case Based) pada Mata Kuliah Statistika Pendidikan. Jurnal Penelitian Pembelajaran Matematika, 13(2), 256-267. http://dx.doi.org/10.30870/jppm.v13i2.8768\%0A

Saputra, K. A. K., Koswara, M. K., \& Atmadja, A. T. A. (2017). Pengaruh Penerapan Metode Case-Based Learning dan Motivasi Terhadap Pemahaman Akuntansi Forensik Dengan Kecerdasan Emosional Sebagai Variabel Pemoderasi. Simposium Nasional Akuntansi XX, Universitas Jember. http://www.academia.edu/download/56337500/Full_Paper_Komang_Adi_dkk.pdf

Sari, B. K. (2017). Desain Pembelajaran Model ADDIE dan Impelentasinya dengan Teknik Jigsaw. Prosiding Seminar Nasional Pendidikan: Tema "Desain Pembelajaran Di Era ASEAN Economic Community (AEC) Untuk Pendidikan Indonesia Berkemajuan,” 87-102. http://eprints.umsida.ac.id/432/1/ARTIKEL Bintari Kartika Sari.pdf

Supriyadi. (2013). Strategi Belajar dan Mengajar. Yogyakarta: Dua Satria Offset.

Sustiawati, N. L., Suryatini, N. K., \& Mayun Artati, A. A. A. (2018). Pengembangan Desain Pembelajaran Seni Tari Di Sekolah Dasar Berbasis Localgenius Knowledge Berpendekatan Integrated Learning. Mudra Jurnal Seni Budaya, 33(1), 128-143. https://doi.org/10.31091/mudra.v33i1.322

Sutomo, A. D. (2007). Simulasi Sistem Kontrol Berbasis Plc: Pembelajaran Berbasis 
Pembelajaran Berbasis Kasus pada Matakuliah Programmable Logic Controller. Seminar Nasional III SDM Teknologi Nuklir, November, 371-376. https://www.researchgate.net/publication/242532042

Thistlethwaite, J. E., Davies, D., Ekeocha, S., Kidd, J. M., MacDougall, C., Matthews, P., Purkis, J., \& Clay, D. (2012). The Effectiveness of Case-Based Learning in Health Professional Education. A BEME Systematic Review: BEME Guide No. 23. Medical Teacher, 34(6), 142-159. https://doi.org/10.3109/0142159X.2012.680939

Purwanto, M. N. (2013). Prinsip-prinsip dan Teknik Evaluasi Pengajaran. Bandung, ID: PT. Remaja Rosdakarya.

Ulfiyani, S. (2018). Pembelajaran Keterampilan Berbicara Berbasis Kasus: Upaya Peningkatan Keterampilan Berpikir Kritis Mahasiswa. Prosiding Seminar Nasional, Pertemuan Ilmiah Bahasa Dan Sastra Indonesia (PIBSI) XL 2018, 351-362. https://proceeding.unikal.ac.id/index.php/pibsi40/article/view/98

Uno, H.B. (2011). Desain Pembelajaran. MOS Publishing. Gorontalo.

Uno, H.B. (2014). Perencanaan Pembelajaran. Bumi Aksara. Jakarta.

Williams, B. (2005). Case Based Learning-a Review of The Literature: Is There Scope for This Educational Paradigm in Prehospital Education? Emergency Medicine Journal, 22(8), 577581. https://doi.org/10.1136/emj.2004.022707 